\title{
Cannabinoid Type 1 Receptor Gene Polymorphism and Macronutrient Intake
}

\author{
Maria Gabriella Caruso ${ }^{a}$ Patrizia Gazzerro ${ }^{c}$ Maria Notarnicola ${ }^{a}$ \\ Anna Maria Cisternino ${ }^{b}$ Vito Guerrab Giovanni Misciagna ${ }^{b}$ \\ Chiara Laezza $^{d}$ Maurizio Bifulco ${ }^{c}$ \\ a Laboratory of Biochemistry and b' Laboratory of Epidemiology and Biostatistics, National \\ Institute for Digestive Diseases, 'Saverio de Bellis', Castellana Grotte, 'Department of \\ Pharmaceutical Sciences, University of Salerno, Fisciano, and ${ }^{\mathrm{d} I n s t i t u t e}$ of Endocrinology \\ and Experimental Oncology, CNR, Naples, Italy
}

\section{Key Words}

Cannabinoid receptor $\cdot$ Nutrients $\cdot$ Gene polymorphism $\cdot$ Population study $\cdot$ Phenotype

\begin{abstract}
Background: Cannabinoid type 1 receptor (CB1-R) is a key mediator in the control of food intake and is linked to obesity. Aim: To evaluate the relationship between CB1-R gene polymorphism and dietary macronutrient intake in elderly subjects. Methods: This study included 118 subjects (60 males, 58 females) from a population survey carried out in southern Italy in 1992-1993 who were older than 65 years and previously characterized for CB1-R polymorphism (75 with GG wild-type genotype, 41 with heterozygous polymorphic allele $A G$, and 2 with genotype AA). All subjects completed a validated semi-quantitative food frequency questionnaire. Statistical methods included multiple logistic regression to model macronutrient intake to genotype, controlling for potential confounders. Results: When controlled for age, gender, and body mass index, the intake of dietary cholesterol and saturated fats corrected for calories was inversely associated with the CB1-R $1359 \mathrm{G} / \mathrm{A}$ polymorphism, while the intake of starchy carbohydrates was directly associated with this polymorphism. Conclusion: In our unselected elderly population, the $1359 \mathrm{G} / \mathrm{A}$ polymorphism is linked with a specific macronutrient intake. This could be explained by the role of the cannabinoid system as a determinant of food intake and eating behavior.




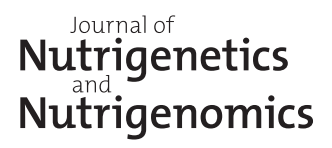

\begin{tabular}{l|l}
\hline \begin{tabular}{l} 
J Nutrigenet Nutrigenomics 2012;5:305-313 \\
\hline DOI: 10.1159/000343563 \\
Published online: November 27, 2012
\end{tabular} & $\begin{array}{l}\text { @ 2012 S. Karger AG, Basel } \\
\text { www.karger.com/jnn }\end{array}$ \\
\hline Caruso et al.: Cannabinoid Type 1 Receptor Gene Polymorphism and Macronutrient Intake
\end{tabular}

\section{Introduction}

Obesity is considered a worldwide epidemic in modern societies, affecting all ages, genders, and ethnic groups. Increased adiposity is due to the interaction between a genetic background and environmental factors, particularly excessive food intake and reduced physical activity. Although the obesity epidemic has been certainly driven by lifestyle and environmental changes, it is also clear that there is individual variation in response to these factors, suggesting a strong genetic predisposition. In recent years, in this scenario the role of the endocannabinoid system has been emerging.

The endocannabinoid system controls food intake, energy balance, and lipid and glucose metabolism [1]. It has both central and peripheral effects and stimulates lipogenesis and fat accumulation [1]. Moreover, there is evidence suggesting that cannabinoid type 1 receptor (CB1-R) and endocannabinoids are involved in regulating the energy balance, influencing eating behavior and body weight [2]. The endocannabinoid system is overactivated in genetic animal models of obesity and in response to exogenous stimuli such as excessive food intake $[3,4]$. Preclinical studies implicated the endocannabinoid system in the modulation of food intake and adipogenesis, through peripheral mechanisms, and the system might provide a possible treatment target for high-risk overweight or obese patients [5]. A greater insight into the endocannabinoid system has been gained from studies in animals with a genetic deletion of CB1-R, which have a lean phenotype and are resistant to diet-induced obesity and the associated insulin resistance produced by a highly palatable high-fat diet [6]. Further evidence was derived from investigations using the selective CB1-R blocker rimonabant, which produces weight loss and ameliorates metabolic abnormalities in obese animals and humans $[7,8]$. The endocannabinoid system has also been found to affect the choice of foods in animal models [9]. Overall, these findings conclusively prove the hypothesis that a hyperactive endocannabinoid system is a factor contributing to obesity and related disorders.

Mammalian tissues contain at least two types of cannabinoid receptors, CB1 and CB2 receptors $[10,11]$. CB1-Rs are located in several areas of the brain and in a variety of tissues such as adipose tissue, muscle, the gastrointestinal tract including the liver, and the pancreas, breast, thyroid, and prostate. CB2-Rs are located in immune cells such as T-cells, B-cells, monocytes, spleen, tonsils, and dendritic cells. Both cannabinoid receptors are G-proteincoupled transmembrane receptors.

Several studies have shown an association between CB1-R gene polymorphisms and obesity in humans [12-16]. Previously, we evaluated, at the population level, the frequency of a genetic polymorphism of the CB1-R gene (1359 G/A) and its correlation with body mass index (BMI), showing that the presence of the CB1 polymorphic A allele was significantly associated with a lower BMI [17].

Therefore, we decided to investigate, in the same population sample, whether this CB1-R polymorphism could also be related to macronutrient intake. In fact, CB1-R seems to be involved in motivational processes such as appetite and satiety, and also in specific food preference [9]. It has been reported that blockade of CB1-Rs suppressed intake of sweet foods in rodents $[18,19]$. A more recent study found a specific effect of the CB1-R antagonist on preferred palatable food intake in non-human primates [20]. The role of CB1-Rs on macronutrient selection has also been demonstrated in rats, where the stimulation of food intake induced by CB1-R activation involves a specific dietary component and behavioral selective mechanisms [21]. No data exist on the association between the A allele of the CB1-R 1359 G/A polymorphism and macronutrient intake in humans. 


\section{Nutrigenetics \\ Nutrigenomics}

\begin{tabular}{l|l}
\hline J Nutrigenet Nutrigenomics 2012;5:305-313 \\
\hline DOI: 10.1159/000343563 & $\begin{array}{l}\text { @ 2012 S. Karger AG, Basel } \\
\text { www.karger.com/jnn }\end{array}$ \\
\hline Published online: November 27, 2012
\end{tabular}

Caruso et al.: Cannabinoid Type 1 Receptor Gene Polymorphism and Macronutrient Intake

\section{Materials and Methods}

\section{Study Design and Patients}

This work is part of the MICOL study, a 25-year longitudinal population study on gallstones, which began in 1985 in a small town in southern Italy (Castellana, Province of Bari, in the Apulia region). Briefly, between May 1985 and June 1986, 3,500 individuals (2,000 men and 1,500 women aged 30-69 years) were randomly selected from the electoral register of the town (the register includes all residents of the town over 18 years of age, and therefore old enough to vote). Of these, 2,472 subjects ( $70.6 \%$ respondence rate, 1,429 men and 1,043 women) participated in the survey. Between May 1992 and June 1993, 2,175 of these subjects were re-examined ( $88 \%$ respondence rate). After agreeing to participate, all subjects were asked to complete a validated semi-quantitative food frequency questionnaire (FFQ) and to respond to questions on sociodemographic variables, lifestyle, and medical history all reported in the previous year, and underwent standardized measurement of height, weight, and blood pressure. A blood sample was also taken at the examination in the morning, with the subjects fasting for at least $12 \mathrm{~h}$, and kept in a biological bank at $-80^{\circ} \mathrm{C}$. In this report, we present data obtained from a random subsample of 118 elderly subjects at the second examination (1992-1993), already previously examined for the CB1-R 1359 G/A polymorphism [17], who have filled out their FFQ. Among these subjects, 75 carried the GG wild-type genotype, 41 carried the polymorphic allele AG, and only 2 carried the allele AA. Since the characteristics (anthropometric and laboratory measurements) of 2 subjects with genotype AA were similar to that of genotype AG, we decided to study these two genotypes together, creating the new category AA+AG. All subjects were older than 65 years and younger than 75 years in order to minimize, or at least to reduce, the influence of other behavioral, physiological variables. The project was approved by the Institutional Review Board (IRB) of IRCCS De Bellis, and informed consent was obtained from each participant before entering the study.

\section{Food Exposure Measurement}

The questionnaire was structured in 4 sections: demographic data, physiological and pathological history, and questions regarding daily diet as well as physical activity. The questionnaire was designed to be easily comprehensible with brief questions and closed answers, thus providing a useful tool to correctly classify the consumption level of food intake and the identification of comorbidities, vitamins, drug intake, and smoking habits. The FFQ section requested information about the intake of 124 foods and drinks clustered into 96 food items, organized into 12 sections of homogeneous food groups, considering caloric contribution and nutritional supply, consumed during the 12 months before enrolment in the study. For each food, the questionnaire required the weekly consumption, and for certain foods also the portion size. The food conversion into nutrients and calories was performed using the Italian National Institute of Nutrition Food Composition Tables described by Fidanza [22]. The FFQ was validated in a population of 100 subjects with two 7-day complete dietary records, which were obtained 6 months apart [23]. The same FFQ had been already used in a study that explored the relationship between diet and gallstones as well as myocardial infarction [24, 25]. The FFQ was self-administered and reviewed with the subjects by an interviewer for completeness. For each subject, all nutrients were calculated as daily consumption.

\section{Genotyping}

The expression of the polymorphic A allele in the CNR1 gene coding for CB1-R was determined using multiplex PCR as previously described [26] and performed by an operator blinded to the patients, their medical history, and eating habits. Briefly, DNA from patients was amplified using a set of two external primers (forward and reverse) able to amplify a region of $400 \mathrm{nt}$ containing the polymorphic site and, in the same tube, a set of four primers able to recognize and to specifically and exclusively anneal the sequence containing the polymorphic nucleotide. As a result, the multiple bands visible in the electrophoretic gel identified the specific polymorphic variants as bands of different size lower than $400 \mathrm{nt}$.

We used PCR primers F1-F (5'-AAGACGGTGTTTGCATTCTG-3') and THAC-R (5'-AAATTCTTTTCCTGTGCTGCCAGGGAG-3'), and allele-specific primers A3-F (5'-AGTGAGAGTTGCATCAAGAGCACA-3') and T1-R (5'-GACTTGGCAATCTTGACT-3') or G4-F (5'-AGTGAGAGTTGCATCAAGAGCACG-3') and C2-R (5'-ACTTGGCAATCTTGACC- ${ }^{\prime}$ ) were used to detect the polymorphic A allele or $\mathrm{G}$ allele, respectively. 


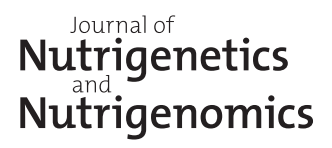

\begin{tabular}{l|l}
\hline \begin{tabular}{l} 
J Nutrigenet Nutrigenomics 2012;5:305-313 \\
\hline DOI: 10.1159/000343563 \\
Published online: November 27, 2012
\end{tabular} & $\begin{array}{l}\text { @ 2012 S. Karger AG, Basel } \\
\text { www.karger.com/jnn }\end{array}$ \\
\hline Caruso et al.: Cannabinoid Type 1 Receptor Gene Polymorphism and Macronutrient Intake
\end{tabular}

Measurement

Anthropometric measurements were taken by the same trained person, with participants wearing scrub suits and no shoes. Body weight was measured using a calibrated scale (Detecto; model 437). Standing height was measured with a vertical metal ruler. BMI was calculated as weight in kilograms divided by height in meters squared $\left(\mathrm{kg} / \mathrm{m}^{2}\right)$. Participants fasted for $12 \mathrm{~h}$ before examination. With the subjects seated, fasting blood was drawn from an antecubital vein into vacuum tubes containing ethylenediamine tetraacetic acid (lipids) or a serum separator gel (glucose). Blood serum and plasma aliquots were stored at $-70^{\circ} \mathrm{C}$. Total cholesterol and total triglycerides were measured by enzymatic methods; high-density lipoprotein cholesterol was measured after dextran-magnesium precipitation. Serum glucose was assayed by the hexokinase/glucose-6-phosphate dehydrogenase method. Alanine aminotransferase was determined by the enzymatic colorimetric method. The coefficient of variation when checking the precision of the measurement on the same day was less than $2 \%$.

\section{Statistical Analysis}

Means and standard deviations (SD) for continuous variables and relative frequencies for categorical variables were used as indices of centrality and dispersion of the distribution. All variables studied in the genotype categories were compared using the Mann-Whitney test and $\chi^{2}$ test. For all dietary variables, the Mann-Whitney test was used because the distribution was not normal. Multiple logistic regression was used to investigate the association between the genotypes and the macronutrient intake, corrected for calories and controlling for age, gender, and BMI. The amount of macronutrients has been divided into quartiles of intake, with the lowest quartile considered as baseline towards the upper quartiles. The statistical significance was set at $\mathrm{p} \leq 0.05$. The Stata 10 statistical package was used for data management and analysis (Stata Corporation, College Station, Tex., USA).

\section{Results}

Table 1 shows the means \pm SD for continuous variables and the frequencies for categorical variables in the different genotype categories. There were no significant differences in anthropometrical variables and laboratory parameters between the genotype groups. We found statistically significant differences in cholesterol and saturated fat measures between the genotypes $(184.6 \pm 97.6$ vs. $140 \pm 95.6 \mathrm{mg} /$ day, $\mathrm{p}=0.005$, and $22.7 \pm 10.9$ vs. $18.7 \pm$ $10.0 \mathrm{~g} /$ day, $\mathrm{p}=0.04$, respectively).

Table 2 shows the odds ratio (OR) and 95\% confidence interval (CI) of the OR for the allele A variant for quartiles of each dietary variable compared to the lowest quartile, corrected for calories and controlling for age, gender, and BMI ( $\geq 30)$, using unconditional logistic regression. There were no differences in proteins, lipids, available and soluble carbohydrates, fiber, alcohol, and monounsaturated and polyunsaturated fats. The intake of complex carbohydrates, predominantly starch, for the upper quartile as compared to the lowest quartile, corrected for calories, was directly associated with the CB1-R 1359 G/A polymorphism (OR 3.49; 95\% CI $0.99-12.32)$, and the test for trend was also significant $(\mathrm{p}=0.01)$. On the contrary, the intake of dietary cholesterol and saturated fats for the upper quartile compared to the baseline quartile was inversely associated with the CB1-R 1359 G/A polymorphism (OR 0.28; 95\% CI 0.09-0.92 for dietary cholesterol, and OR $0.29 ; 95 \%$ CI $0.09-0.91$ for saturated fat), and the test for trend was significant for dietary cholesterol $(\mathrm{p}=0.03)$ and borderline for saturated fat $(\mathrm{p}=0.07)$.

\section{Discussion}

In this study, we showed that the 1359 G/A CB1-R gene polymorphism was associated with a specific macronutrient intake in a sample of elderly individuals. After controlling for age, gender, and BMI, the intake of complex carbohydrates, predominantly starch, for the 
Table 1. Descriptive analysis of the studied variables in the different genotype groups

\begin{tabular}{|c|c|c|c|}
\hline & \multicolumn{2}{|l|}{ Genotype } & \multirow[t]{2}{*}{ p value ${ }^{*}$} \\
\hline & $\mathrm{GG}(\mathrm{n}=75)$ & $\mathrm{AA}+\mathrm{AG}(\mathrm{n}=43)$ & \\
\hline \multicolumn{4}{|l|}{ Patient characteristics } \\
\hline Male gender & $40(53.3)$ & $20(46.5)$ & 0.48 \\
\hline Age, years & $69.7 \pm 3.4$ & $70.4 \pm 3.2$ & 0.28 \\
\hline $\mathrm{BMI}$ & $28.9 \pm 5.7$ & $27.8 \pm 6.4$ & 0.28 \\
\hline $\mathrm{BMI} \geq 30, \%$ & 38.7 & 27.9 & 0.23 \\
\hline Cholesterol, mg/dl & $196.6 \pm 38.4$ & $196.4 \pm 34.6$ & 0.87 \\
\hline HDL cholesterol, mg/dl & $51.6 \pm 13.5$ & $48.3 \pm 12.5$ & 0.23 \\
\hline Triglycerides, mg/dl & $122.5 \pm 106.2$ & $132.5 \pm 124.2$ & 0.96 \\
\hline Glycemia, mg/dl & $105.0 \pm 31.4$ & $116.5 \pm 42.8$ & 0.44 \\
\hline GPT, IU/dl ${ }^{-1}$ & $16.1 \pm 8.3$ & $17.3 \pm 13.7$ & 0.68 \\
\hline \multicolumn{4}{|l|}{ Dietary variables } \\
\hline Proteins, g/day & $69.4 \pm 27.0$ & $60.9 \pm 30.5$ & 0.06 \\
\hline Lipids, g/day & $85.9 \pm 33.4$ & $75.8 \pm 32.1$ & 0.06 \\
\hline Available carbohydrate, g/day & $273.4 \pm 120.1$ & $266.7 \pm 127.8$ & 0.77 \\
\hline Starch, g/day & $148 \pm 73.5$ & $160.0 \pm 86.0$ & 0.50 \\
\hline Soluble carbohydrate, g/day & $106.5 \pm 65.3$ & $86.8 \pm 45.0$ & 0.24 \\
\hline Fiber, g/day & $26.9 \pm 14.0$ & $24.0 \pm 12.2$ & 0.44 \\
\hline Soluble fiber & $8.4 \pm 4.3$ & $7.6 \pm 3.9$ & 0.52 \\
\hline Insoluble fiber & $18.0 \pm 10.0$ & $15.8 \pm 8.2$ & 0.39 \\
\hline Saturated fat, g/day & $22.7 \pm 10.9$ & $18.7 \pm 10.0$ & 0.04 \\
\hline Monounsaturated fat, g/day & $46.9 \pm 18.8$ & $42.2 \pm 16.1$ & 0.18 \\
\hline Polyunsaturated fat, g/day & $8.9 \pm 3.3$ & $8.0 \pm 3.5$ & 0.06 \\
\hline Cholesterol, mg/day & $184.6 \pm 97.6$ & $140.6 \pm 95.6$ & 0.005 \\
\hline Alcohol, g/day & $23.8 \pm 24.5$ & $18.6 \pm 23.9$ & 0.21 \\
\hline Calories, $\mathrm{kcal} /$ day & $2,244.1 \pm 814.7$ & $2,058.2 \pm 859.8$ & 0.19 \\
\hline Glycemic index & $57.9 \pm 4.4$ & $58.4 \pm 4.5$ & 0.56 \\
\hline Glycemic load, U/day & $151.5 \pm 71.5$ & $152.3 \pm 79.1$ & 0.99 \\
\hline
\end{tabular}

Values are mean $\pm \mathrm{SD}$ or $\mathrm{n}(\%)$. HDL $=$ High-density lipoprotein; GPT $=$ Glutamic pyruvic transaminase.

${ }^{*} \chi^{2}$ test for categorical variables; Mann-Whitney test for continuous variables.

upper quartile as compared to the lowest quartile was directly associated with the CB1-R 1359 G/A polymorphism; on the contrary, the intake of dietary cholesterol and saturated fats was inversely associated with this polymorphism. To our knowledge, this is the first study that reports such an association in humans, namely a specific polymorphism in the same gene previously associated with lower BMI and now with macronutrient intake. The limitations of self-reported dietary intake are well recognized [27]. Although the FFQ used in the present study has reasonable reproducibility and validity, recalled data have inevitably a large measurement error, which makes it harder to find significant differences between the genotype groups. In addition, we assume that the recall bias was similar for each genotype and, therefore, did not affect the general outcome of our findings.

The CB1-R variant examined (mutant-type group G1359A and A1359A) in the present study has already been associated with a lean-related phenotype and with a better cardiovascular profile (triglyceride, glycemia) than the wild-type group in our MICOL cohort [17].

Although the effect of the polymorphism on the function of CB1-R is unknown, the results favor further evaluations of the endocannabinoid system. In the current study, the 
Table 2. OR and $95 \% \mathrm{CI}$ of $\mathrm{AA}+\mathrm{AG} / \mathrm{GG}$ in quartiles of each dietary variable (upper quartiles compared to the lowest quartile) corrected for calories and controlling for age, gender, and BMI ( $\geq 30)$, using unconditional multiple logistic regression

\begin{tabular}{|c|c|c|c|c|c|c|}
\hline Dietary variables & Quartiles $^{1}$ & OR & SE (OR) & $95 \%$ CI & $\mathrm{p}$ value* & p value ${ }^{\S}$ \\
\hline Proteins (g/day) & $\begin{array}{l}\mathrm{Q}_{2} \\
\mathrm{Q}_{3} \\
\mathrm{Q}_{4}\end{array}$ & $\begin{array}{l}0.73 \\
1.13 \\
0.38 \\
\end{array}$ & $\begin{array}{l}0.39 \\
0.63 \\
0.22 \\
\end{array}$ & $\begin{array}{l}0.25-2.11 \\
0.38-3.36 \\
0.12-1.22\end{array}$ & $\begin{array}{l}0.56 \\
0.82 \\
0.10\end{array}$ & 0.26 \\
\hline Lipids (g/day) & $\begin{array}{l}\mathrm{Q}_{2} \\
\mathrm{Q}_{3} \\
\mathrm{Q}_{4}\end{array}$ & $\begin{array}{l}1.30 \\
0.79 \\
0.49\end{array}$ & $\begin{array}{l}0.72 \\
0.44 \\
0.28\end{array}$ & $\begin{array}{l}0.44-3.83 \\
0.27-2.37 \\
0.15-1.54\end{array}$ & $\begin{array}{l}0.63 \\
0.68 \\
0.22\end{array}$ & 0.25 \\
\hline Carbohydrates (g/day) & $\begin{array}{l}\mathrm{Q}_{2} \\
\mathrm{Q}_{3} \\
\mathrm{Q}_{4}\end{array}$ & $\begin{array}{l}0.90 \\
1.18 \\
1.50 \\
\end{array}$ & $\begin{array}{l}0.53 \\
0.68 \\
0.83 \\
\end{array}$ & $\begin{array}{l}0.29-2.84 \\
0.38-3.65 \\
0.51-4.42\end{array}$ & $\begin{array}{l}0.86 \\
0.77 \\
0.46\end{array}$ & 0.15 \\
\hline Alcohol (g/day) & $\begin{array}{l}\mathrm{Q}_{2} \\
\mathrm{Q}_{3} \\
\mathrm{Q}_{4}\end{array}$ & $\begin{array}{l}1.42 \\
1.49 \\
0.47 \\
\end{array}$ & $\begin{array}{l}0.78 \\
0.83 \\
0.29 \\
\end{array}$ & $\begin{array}{l}0.48-4.18 \\
0.50-4.43 \\
0.14-1.59\end{array}$ & $\begin{array}{l}0.52 \\
0.47 \\
0.22\end{array}$ & 0.72 \\
\hline $\begin{array}{l}\text { Complex carbohydrates } \\
\text { (g/day) }\end{array}$ & $\begin{array}{l}\mathrm{Q}_{2} \\
\mathrm{Q}_{3} \\
\mathrm{Q}_{4}\end{array}$ & $\begin{array}{l}2.91 \\
3.07 \\
3.49\end{array}$ & $\begin{array}{l}1.83 \\
1.91 \\
2.25\end{array}$ & $\begin{array}{l}0.85-9.97 \\
0.91-10.38 \\
0.99-12.32\end{array}$ & $\begin{array}{l}0.09 \\
0.07 \\
0.05\end{array}$ & 0.01 \\
\hline Simple carbohydrates (g/day) & $\begin{array}{l}\mathrm{Q}_{2} \\
\mathrm{Q}_{3} \\
\mathrm{Q}_{4}\end{array}$ & $\begin{array}{l}1.11 \\
0.62 \\
0.67\end{array}$ & $\begin{array}{l}0.61 \\
0.35 \\
0.38 \\
\end{array}$ & $\begin{array}{l}0.38-3.25 \\
0.21-1.88 \\
0.22-2.03\end{array}$ & $\begin{array}{l}0.85 \\
0.40 \\
0.48\end{array}$ & 0.15 \\
\hline Fiber (g/day) & $\begin{array}{l}\mathrm{Q}_{2} \\
\mathrm{Q}_{3} \\
\mathrm{Q}_{4}\end{array}$ & $\begin{array}{l}1.22 \\
1.50 \\
0.62 \\
\end{array}$ & $\begin{array}{l}0.66 \\
0.88 \\
0.36\end{array}$ & $\begin{array}{l}0.42-3.55 \\
0.47-4.77 \\
0.20-1.97\end{array}$ & $\begin{array}{l}0.72 \\
0.49 \\
0.42\end{array}$ & 0.64 \\
\hline Soluble fiber (g/day) & $\begin{array}{l}\mathrm{Q}_{2} \\
\mathrm{Q}_{3} \\
\mathrm{Q}_{4}\end{array}$ & $\begin{array}{l}2.09 \\
2.20 \\
0.65\end{array}$ & $\begin{array}{l}1.18 \\
1.27 \\
0.40\end{array}$ & $\begin{array}{l}0.69-6.33 \\
0.71-6.80 \\
0.19-2.16\end{array}$ & $\begin{array}{l}0.19 \\
0.17 \\
0.48\end{array}$ & 0.77 \\
\hline Insoluble fiber (g/day) & $\begin{array}{l}\mathrm{Q}_{2} \\
\mathrm{Q}_{3} \\
\mathrm{Q}_{4}\end{array}$ & $\begin{array}{l}2.01 \\
1.48 \\
0.62 \\
\end{array}$ & $\begin{array}{l}1.12 \\
0.84 \\
0.37 \\
\end{array}$ & $\begin{array}{l}0.67-6.02 \\
0.49-4.50 \\
0.19-2.02\end{array}$ & $\begin{array}{l}0.21 \\
0.49 \\
0.43\end{array}$ & 0.50 \\
\hline Cholesterol (mg/day) & $\begin{array}{l}\mathrm{Q}_{2} \\
\mathrm{Q}_{3} \\
\mathrm{Q}_{4}\end{array}$ & $\begin{array}{l}0.62 \\
0.45 \\
0.28\end{array}$ & $\begin{array}{l}0.34 \\
0.27 \\
0.17\end{array}$ & $\begin{array}{l}0.21-1.84 \\
0.14-1.45 \\
0.09-0.92\end{array}$ & $\begin{array}{l}0.39 \\
0.18 \\
0.04\end{array}$ & 0.03 \\
\hline Saturated fat (g/day) & $\begin{array}{l}\mathrm{Q}_{2} \\
\mathrm{Q}_{3} \\
\mathrm{Q}_{4}\end{array}$ & $\begin{array}{l}0.41 \\
0.76 \\
0.29\end{array}$ & $\begin{array}{l}0.23 \\
0.43 \\
0.17\end{array}$ & $\begin{array}{l}0.14-1.23 \\
0.25-2.28 \\
0.09-0.91\end{array}$ & $\begin{array}{l}0.11 \\
0.63 \\
0.03\end{array}$ & 0.07 \\
\hline Monounsaturated fat (g/day) & $\begin{array}{l}\mathrm{Q}_{2} \\
\mathrm{Q}_{3} \\
\mathrm{Q}_{4}\end{array}$ & $\begin{array}{l}1.37 \\
1.38 \\
0.78 \\
\end{array}$ & $\begin{array}{l}0.75 \\
0.80 \\
0.45\end{array}$ & $\begin{array}{l}0.47-4.01 \\
0.44-4.30 \\
0.26-2.39\end{array}$ & $\begin{array}{l}0.56 \\
0.58 \\
0.67\end{array}$ & 0.43 \\
\hline Polyunsaturated fat (g/day) & $\begin{array}{l}\mathrm{Q}_{2} \\
\mathrm{Q}_{3} \\
\mathrm{Q}_{4}\end{array}$ & $\begin{array}{l}1.78 \\
0.95 \\
0.65\end{array}$ & $\begin{array}{l}0.97 \\
0.54 \\
0.39\end{array}$ & $\begin{array}{l}0.61-5.20 \\
0.31-2.91 \\
0.20-2.13\end{array}$ & $\begin{array}{l}0.29 \\
0.93 \\
0.48\end{array}$ & 0.56 \\
\hline
\end{tabular}

All dietary variables were calculated from the FFQ.

${ }^{1} \mathrm{Q}_{1}$ is the reference category for all dietary variables. ${ }^{*} \mathrm{p}$ value for association; ${ }^{\S} \mathrm{p}$ value for linear trend on nutrient, corrected for calories. 
subjects with the polymorphic variant followed a diet in which less energy was derived from fat (less saturated fats and dietary cholesterol) and more energy was derived from carbohydrates (predominantly starch) compared with the diet of the subjects homozygous for the wild-type allele. Our findings show that genotyping for CB1-R is linked to differences in the choice of foods. Feeding can be stimulated under various physiological conditions and can be driven by distinct nutritional and other signals. Much evidence suggests that cannabinoids increase the drive to eat specifically by enhancing the reward or hedonic properties of food. Within the central nervous system, CB1-Rs are expressed particularly in areas, such as the nucleus accumbens, hippocampus, and entopeduncular nucleus, which are either directly involved in the hedonic aspects of eating or are connected to reward-related brain areas $[28,29]$. A study in rats has demonstrated that increased activity of the cannabinoid system determines appetite for palatable food, and thus potentially determines the severity of diet-induced obesity in this experimental model [30]. Di Marzo et al. [31] have shown that a hedonic stimulus (chronic delta-9 THC administration) can release anandamide in the limbic forebrain.

Hence, components of the palatable diet itself could be responsible for the intake of palatable food. 2-Arachidonoylglycerol is known to accumulate in the intestine during the digestion of dietary triglycerides [32]. Endocannabinoids are rapidly hydrolyzed in the intestine and in the liver, and thus may not reach the brain in sufficient quantities to interact with central CB1-Rs. It is possible, however, that endogenous cannabinoids generated following ingestion of relatively triglyceride-rich palatable food could override local satiety pathways by binding to gut cannabinoid receptors [33]. Furthermore, empirical evidence indicates that activation of CB1-R increases palatable food intake; however, high-energy diets also produce changes in endocannabinoid levels [34]. Increased and chronic activation of CB1-Rs may be both a cause and a consequence of palatable high-energy food intake.

To date, we have no evidence of mRNA CB1-R stability or protein expression levels in allele A carriers, but the significant association between the presence of the polymorphic variant and a specific macronutrient intake is an intriguing issue. Further studies in other populations are needed to confirm our findings, but our data have strong implications on the potential of genotyping to create targeted personalized dietary programs. Pharmacological targeting of the cannabinoid system may prove particularly useful in the treatment of overconsumption of palatable food, which is an important factor contributing to lifestylerelated obesity in humans.

The polymorphic variant of CB1-R examined in the present study has already been associated with a lean-related phenotype. Now, on the basis of its association with a specific macronutrient intake, we can hypothesized that differences in food preference in carriers of this polymorphism mediate lower adiposity.

\section{Disclosure Statement}

The authors declare that there is no competing financial interest in relation to the work described. 


\section{Journal of \\ Nutrigenetics \\ Nutrigenomics}

J Nutrigenet Nutrigenomics 2012;5:305-313

\begin{tabular}{l|l}
\hline DOI: $10.1159 / 000343563$ \\
Published online: November 27, 2012 & $\begin{array}{l}\text { ○ 2012 S. Karger AG, Basel } \\
\text { www.karger.com/jnn }\end{array}$ \\
\hline
\end{tabular}

Caruso et al.: Cannabinoid Type 1 Receptor Gene Polymorphism and Macronutrient Intake

\section{References}

1 Engeli S: Central and peripheral cannabinoid receptors as therapeutic targets in the control of food intake and body weight. Handb Exp Pharmacol 2012;209:357-381.

2 Pagotto U, Pasquali R: Endocannabinoids and energy metabolism. J Endocrinol Invest 2006;29:66-76.

- 3 Di Marzo V, Matias I: Endocannabinoid control of food intake and energy balance. Nat Neurosci 2005;8:585-589.

4 Pagotto U, Marsicano G, Cota D, Lutz B, Pasquali R: The emerging role of the endocannabinoid system in endocrine regulation and energy balance. Endocr Rev 2006;23:73-100.

5 Engeli S, Jana B, Mareike F, Kerstin G, Jurgen J, Sandor B: Activation of the peripheral endocannabinoid system in human obesity. Diabetes 2005;54:2838-2843.

6 Ravinet TC, Delgorge C, Menet C, Arnone M, Soubrie P: CB1 cannabinoid receptor knockout in mice leads to leanness, resistance to diet-induced obesity and enhanced leptin sensitivity. Int J Obes Relat Metab Disord 2004;28:640648.

7 Lazzari P, Sanna A, Mastinu A, Cabasino S, Manca I, Pani L: Weight loss induced by rimonabant is associated with an altered leptin expression and hypothalamic leptin signaling in diet-induced obese mice. Behav Brain Res 2010;217: $432-438$.

8 Leite CE, Mocelin CA, Petersen GO, Leal MB, Thiesen FV: Rimonabant: an antagonist drug of the endocannabinoid system for the treatment of obesity. Pharmacol Rep 2009;61:217-224.

-9 Harrold JA, Elliott JC, King PJ, Widdowson PS, Williams G: Down-regulation of cannabinoid-1 (CB-1) receptors in specific extrahypothalamic regions of rats with dietary obesity: a role for endogenous cannabinoids in driving appetite for palatable food? Brain Res 2002;952:232-238.

10 Di Marzo V, Bifulco M, De Petrocellis L: The endocannabinoid system and its therapeutic exploitation. Nat Rev Drug Discov 2004;3:771-784.

11 Felder CC, Glass M: Cannabinoid receptors and their endogenous agonists. Ann Rev Pharmacol Toxicol 1998;38: 179-200.

12 Aberle J, Flitsch J, Alessia N, Mann O, Busch P, Peitsmeier P, et al: Genetic variation may influence obesity only under conditions of diet: analysis of three candidate genes. Mol Genet Metab 2008;95:188-191.

-13 Benzinou M, Chèvre JC, Ward KJ, Lecoeur C, Dina C, Lobbens S, et al: Endocannabinoid receptor 1 gene variations increase risk for obesity and modulate body mass index in European populations. Hum Mol Genet 2008;17:1916-1921. Jaeger J, Mattevi V, Callegari-Jacques SD, Hutz MH: Cannabinoid type 1 receptor gene polymorphisms are associated with central obesity in a Southern Brazilian population. Dis Markers 2008;25:67-74.

15 Peeters A, Beckers S, Mertens I, Van Hul W, Van Gaal L: The G1422A variant of the endocannabinoid receptor gene (CNR1) is associated with abdominal adiposity in obese men. Endocrine 2007;31:138-141.

- 16 Russo P, Strazzullo P, Cappuccio F, Tregouet D, Lauria F, Loguercio M, et al: Genetic variations at the endocannabinoid type 1 receptor gene (CRN1) are associated with obesity phenotypes in men. J Clin Endocrinol Metab 2007;92: 2382-2389.

17 Gazzerro P, Caruso MG, Notarnicola M, Misciagna G, Guerra V, Laezza C, et al: Association between cannabinoid type 1 receptor polymorphism and body mass index in a southern Italian population. Int J Obes 2007;31:908-912.

18 Arnone M, Maruani J, Chaperon F, Thiebot MH, Poncelet M, Soubrie P, et al: Selective inhibition of sucrose and ethanol intake by SR 141716, an antagonist of central cannabinoid (CB1) receptors. Psychopharmacology (Berl) 1997;132: 104-106.

19 Simiand J, Keane M, Keane PE, Soubrie P: SR 141716, a CB1 cannabinoid receptor antagonist, selectively reduces sweet food intake in marmoset. Behav Pharmacol 1998;9:179-181.

20 Foltin RW, Haney M: Effects of the cannabinoid antagonist SR141716 (rimonabant) and d-amphetamine on palatable food and food pellet intake in non-human primates. Pharmacol Biochem Behav 2007;86:766-773.

-21 Escartín-Pérez RE, Cendejas-Trejo NM, Cruz-Martínez AM, González-Hernández B, Mancilla-Díaz JM, Florán-Garduño B: Role of cannabinoid CB1 receptors on macronutrient selection and satiety in rats. Physiol Behav 2009;96: 646-650.

22 Fidanza F: Nutrizione Umana. Napoli, Idelson, 1984

23 Leoci C, Centonze S, Guerra V, Cisternino AM, Misciagna G: Reliability and validity of a semiquantitative food frequency questionnaire. G Ital Nutr Clin Prev 1993;2:58-59.

24 Misciagna G, Centonze S, Leoci C, Guerra V, Cisternino AM, Ceo R, et al: Diet, physical activity, and gallstones: a population-based case-control study in southern Italy. Am J Clin Nutr 1999;69:120-126.

25 Pierucci P, Misciagna G, Ventura MT, Inguaggiato R, Cisternino AM, Guerra VM, et al: Diet and myocardial infarction: a nested case-control study in a cohort of elderly subjects in a Mediterranean area of southern Italy. Nutr Metab Cardiovasc Dis 2012;22:727-733.

-26 Schimdt LG, Samochowiec J, Finckh U, Fiszer-Piosik E, Horodnicki JB, Rommelspacher H, et al: Association of a CB1 cannabinoid receptor gene (CNR1) polymorphism with severe alcohol dependence. Drug Alcohol Depend 2002;65: 221-224.

27 Heaney RP: Nutrient effects: discrepancy between data from controlled trials and observational studies. Bone 1997; 21:469-471.

28 Finkelstein DI, Reeves AK, Horne MK: An electron microscopic tracer study of the projections from entopeduncular nucleus to the ventrolateral nucleus of the rat. Neurosci Lett 1996;211:33-36. 


\section{Nutrigal of Nutrigenomics}

\begin{tabular}{l|l}
\hline J Nutrigenet Nutrigenomics 2012;5:305-313 \\
\hline $\begin{array}{l}\text { DOI: 10.1159/000343563 } \\
\text { Published online: November 27, 2012 }\end{array}$ & $\begin{array}{l}\text { @ 2012 S. Karger AG, Basel } \\
\text { www.karger.com/jnn }\end{array}$ \\
\hline
\end{tabular}

29 Pecina S, Berridge KC: Opioid sites in nucleus accumbens shell mediate eating and hedonic liking for food: map based on microinjection Fos plumes. Brain Res 2000;863:71-86.

-30 Harrold JA, Williams G, Widdowson PS: Early leptin response to a palatable diet predicts dietary obesity in rats: key role of melanocortin-4-receptors in the ventromedial hypothalamic nucleus. J Neurochem 2000;74:1224-1228.

- 31 Di Marzo V, Berrendero F, Bisogno T, Gonzales S, Cavaliere P, Romero J, et al: Enhancement of anandamide formation in the limbic forebrain and reduction of endocannabinoid contents of the striatum of $\Delta 9$-tetrahydrocannabinoltolerant rats. J Neurochem 2000;74:1627-1635.

-32 Mechoulam R, Ben-Shabat S, Hanus L, Liqumsky M, Kaminski NE, Schatz AR, et al: Identification of an endogenous 2-monoglyceride, present in canine gut, that binds to cannabinoid receptors. Biochem Pharmacol 1995;50:83-90.

33 Berger A, Crozier G, Bisogno T, Cavaliere P, Innis S, Di Marzo V: Anandamide and diet: inclusion of dietary arachidonate and docosahexaenoate leads to increased brain levels of the corresponding $\mathrm{N}$-acylethanolamines in piglets. Proc Natl Acad Sci USA 2001;98:6402-6406.

- 34 Matias I, Petrosino S, Racioppi A, Capasso R, Izzo AA, Di Marzo V: Dysregulation of peripheral endocannabinoid levels in hyperglycemia and obesity: effect of high fat diets. Mol Cell Endocrinol 2008;286(suppl 1):S66-S78. 